\title{
A SKY-LECTURE BY THE BUDDHA
}

\author{
Robert L. Brown \\ Cotsen Institute of Archaeology, Los Angeles, CA, USA; rlbrown@humnet.ucla.edu
}

\begin{abstract}
There is a group of sculptures that display a Buddha standing on a winged creature, often flanked by two attendants. These sculptures are associated with the Dvāravati style of art, date to ca. 7th and 8th centuries, and are almost entirely stone. They are unique in the iconography of Buddhist art. Scholars have searched without success for the meaning of these sculptures, looking for possible narrative explanations in Buddhist texts. It is probable that they were associated with stone Wheels of the Law and were raised together with the Wheels on stone pillars. I propose that rather than a specific narrative, they represent the Buddha elevated in the sky and giving a lecture on his Law (dharma). The act of giving a teaching while elevated in the sky is found in numerous textual episodes, an act that the Buddha performed in order to awe and impress listeners on the ground so that they will accept his teachings, or to dominate in a contest with another spiritual teacher. The Wheel of the Law that was the backing of the Flying Buddha represents the Law itself, which was the substance of his lecture.
\end{abstract}

There is a sculpture of the Buddha, standing on a winged animal in the Los Angeles County Museum of Art (LACMA, Figure 1), which represents a particular iconography found on other Dvāravatī sculptures. The LACMA Buddha stands frontally on the head of a very peculiar winged animal and is flanked by two male figures. This iconography is found on a series of stone sculptures in Thailand that date to the $8^{\text {th }}-9^{\text {th }}$ centuries. Despite intense study, the meaning of this unique iconography has never been decisively determined. Nevertheless, considerable information is known, and several interesting theories as to the meaning, use, and importance of such images have been produced (for a summary, see Thamrungrueang 2009).

The Buddha stands frontally with his two hands held symmetrically at chest level and his open palms facing out.
He makes two different hand gestures (mudra). The proper right hand has two bent fingers across the palm (kantakahasta mudra), and the left hand is open (abhaya mudra). The hands are overly large as the artist was concerned that the gestures be easily read by the worshipper. The Buddha's robe (uttarasanga) is worn over both shoulders; the raised two arms create a perfect U-shape of the hem in front. The back of the robe is made unnaturally symmetrical and distinct from the front section of the robe. The undergarment (antaravasaka), a long skirt, is clearly shown under the robe with a sharp demarcation at the waist and the bottom hem at the ankles that flares out to the side, probably indicating that it was wrapped with the folds along each leg rather than worn with the folds between the legs. ${ }^{1}$

The front U-shaped hem is raised up unnaturally high in order to show clearly the hem of the undergarment. The Buddha's face is broad with a large nose and mouth. The hair, with a high usnisa, does not have curls. The halo is without decoration.

The figure on the left is holding an umbrella over the Buddha's head, the top of which is shown above the halo. There was no attempt by the artist to make the handle held by the attendant and the actual umbrella line up, and they are clearly disjointed. The figure holding the umbrella handle wears a short skirt with a belt from which hangs a front flap of cloth. The only jewelry shown is an earring, which has a very large, unusual, flat irregular shape. The headgear is also very unusual, being a tall cone that flares out at the top with a high mound in the center. This headgear is specific to Visnu and Surya, two deities in Southeast Asian sculpture, and indicates their royal and kingly natures. There is evidence from the Vat Eng Khna lintel from $7^{\text {th }}$ century Cambodia that the crown type was worn by a Southeast Asian king during the royal ceremony of consecration (Dupont 1955, Pl. XXVII, Dalsheimer 2001, piece no. 93). However, the figure on the LACMA Buddha standing on the creature, is most likely to be Indra, for whom the royal headgear would also be 


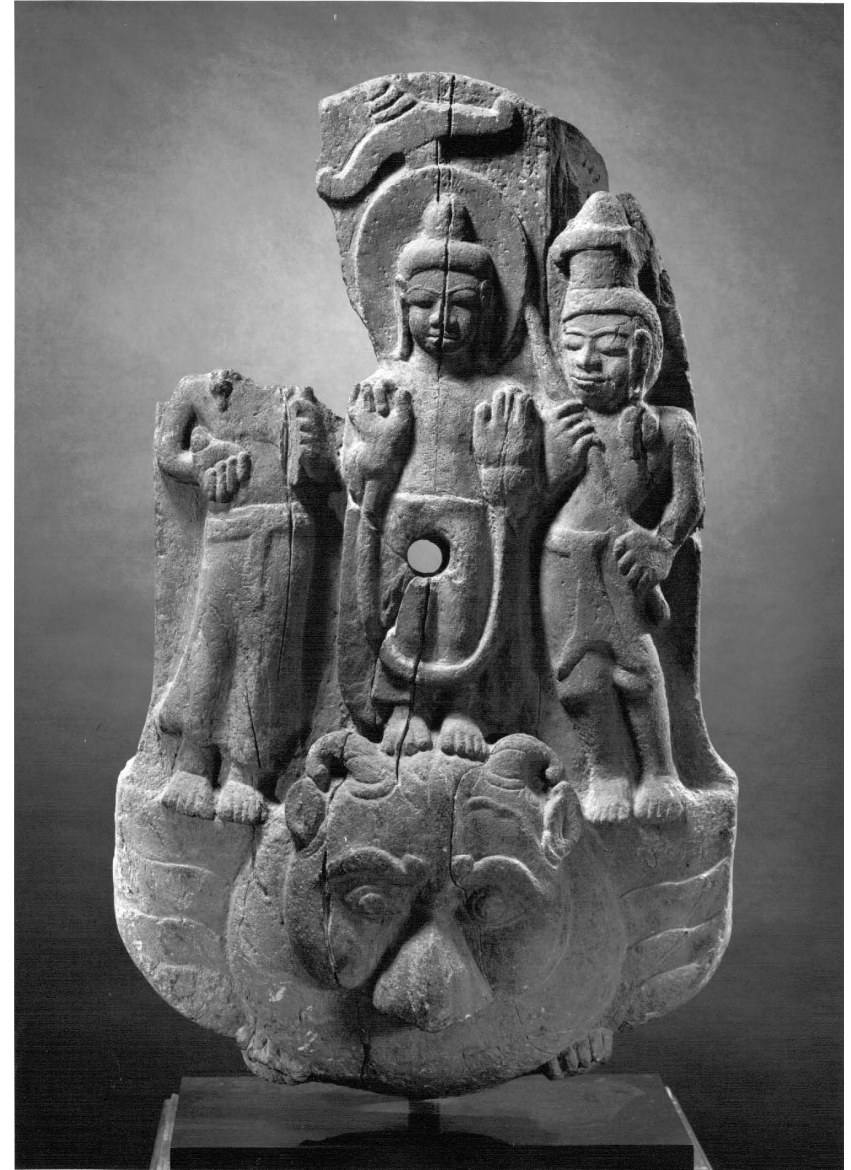

Figure 1. Buddha flanked by figures standing on a mythical creature. From Thailand, 8th to 9th century. Stone, $78.7 \mathrm{~m}$ high, gift of Mr. and Mrs. Harry Lenart, M77.83.

appropriate, considering his kingly nature. Indra is considered the King of the Gods.

The figure on the right is probably Brahma, although the lack of a head makes identification less certain. All that is left is the lower part of an earring that, as with Indra, is unusual in its shape and larger size. He wears a long dhoti and holds in one hand a covered jar and in the other what appears to be a handle, most likely that of a fly whisk (cauri). Comparison to other examples of this iconography, in which the flywhisk is clearly shown held by the figure to Buddha's right, supports this. In one example (see Brown 1996, Figures 78a $\& 78 b$ ) the left-hand figure wears a short skirt and holds the umbrella, while that on the right wears a long skirt and holds the cauri. Thus, the two flanking figures have essentially the same iconography as those on the LACMA sculpture and probably have the same identifications.

While it is likely that these figures are Indra and Brahma, we cannot be certain. The identification is based on

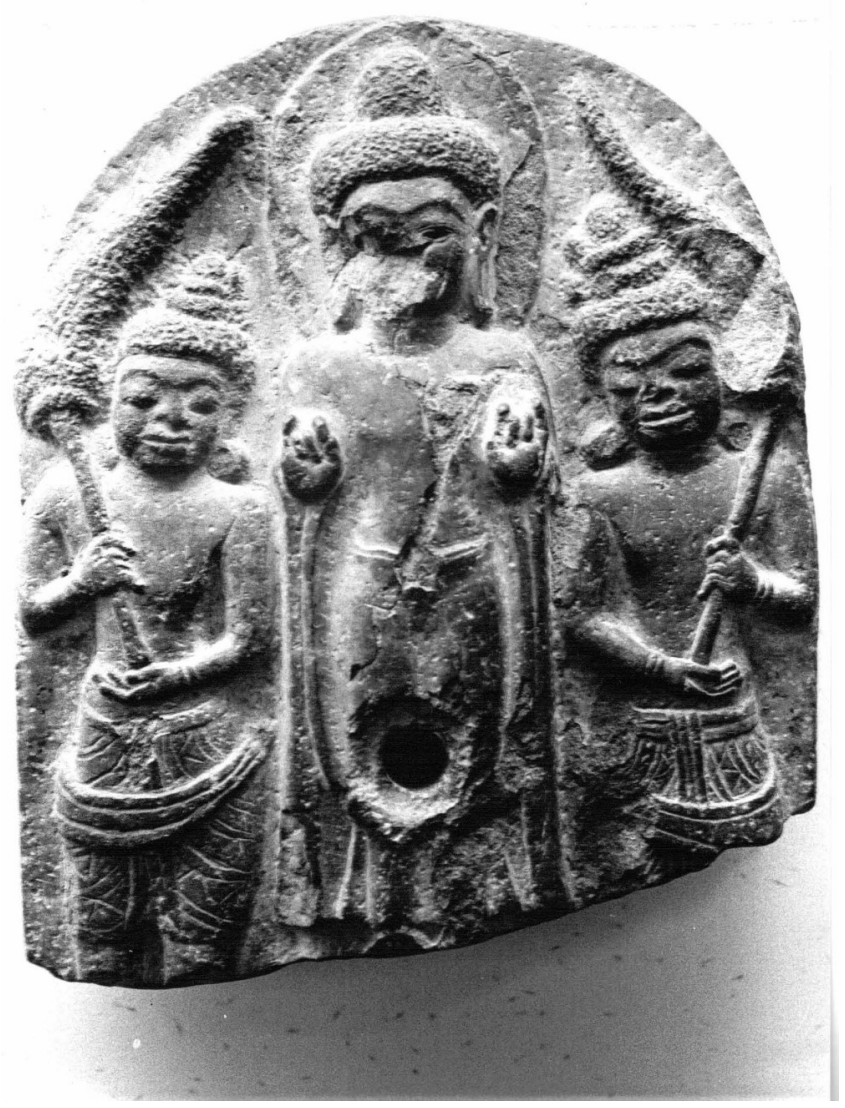

Figure 2. Buddha flanked by figures standing on a mythical creature, now missing due to breakage. From Thailand, 8th to 9th century. Stone, $25 \mathrm{~cm}$ high, National Museum, Bangkok.

comparisons to Buddha triads that show the Buddha's Descent after preaching to his mother in Indra's Heaven (Trayastrimsa). The Descent is depicted in art of South and Southeast Asia and is described in texts as a descent using three side-by-side ladders. ${ }^{2}$ The central ladder of jewels is used by the Buddha, while Indra descends on a ladder of gold on the Buddha's left and Brahma descends on a ladder of silver on his right. Who holds the umbrella varies with the textual reference, although Hsuan Tsang, a Chinese pilgrim writing in the $7^{\text {th }}$ century CE, states that Indra carried the umbrella and Brahma the fly-whisk, as is seen on the LACMA and other Dvāravatī reliefs (Beal, Book IV p. 203). The image of the Buddha accompanied by Indra and Brahma is an indication of his superiority over these formally dominant Vedic deities. ${ }^{3}$ The Descent is part of the Sravasti Miracles cycle, and it ends when the Buddha steps off his ladder at Sankasya and plants his footprint, which then 


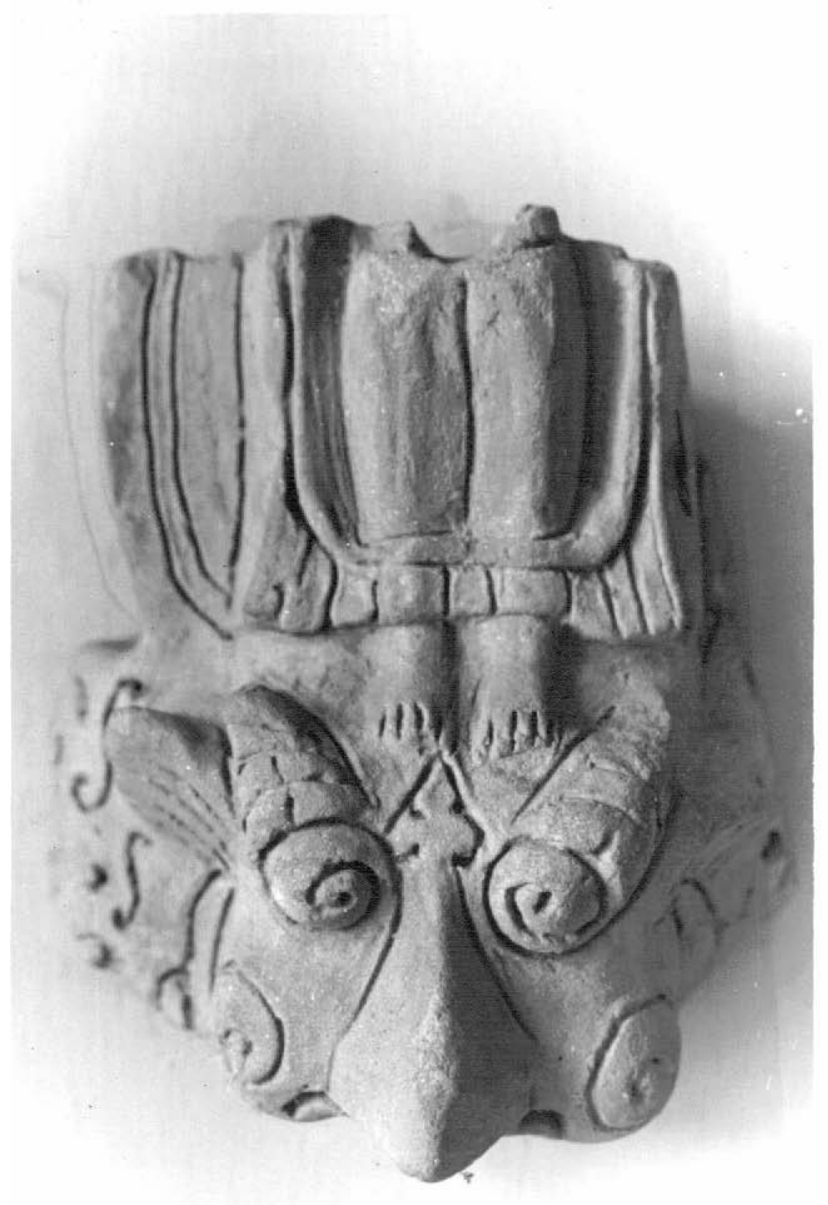

Figure 3. Buddha on a mythical creature. From Thailand, 8th to 9th century. Terra-cotta, $18 \mathrm{~cm}$ high, National Museum, Nakhon Pathom.

becomes the focus of worship (see Huntington 1986, Brown 1984).

No Buddhist text, however, speaks of the Buddha riding on a winged animal. The possible identification of the Buddha flanked by Indra and Brahma has caused scholars to suggest that the use of a flying animal might be a local (Dvāravatī) interpretation of the Descent (Bowie 1960, p. 46). This suggestion has further support in that while the Sravasti sequence has several scenes depicted in Dvāravatī art (Bowie 1960, fig. 17), the very important Descent using a ladder is not shown. The ladder Descent is frequently depicted in Thai art, starting in the Sukhothai period $\left(13^{\text {th }}\right.$ $14^{\text {th }}$ c.) (see Brown 1990).

The LACMA animal is not readily identified, and appears to be made up of several different animals found in Indic iconography. It has a large beak that is placed like a nose, with open staring human eyes covered by very large

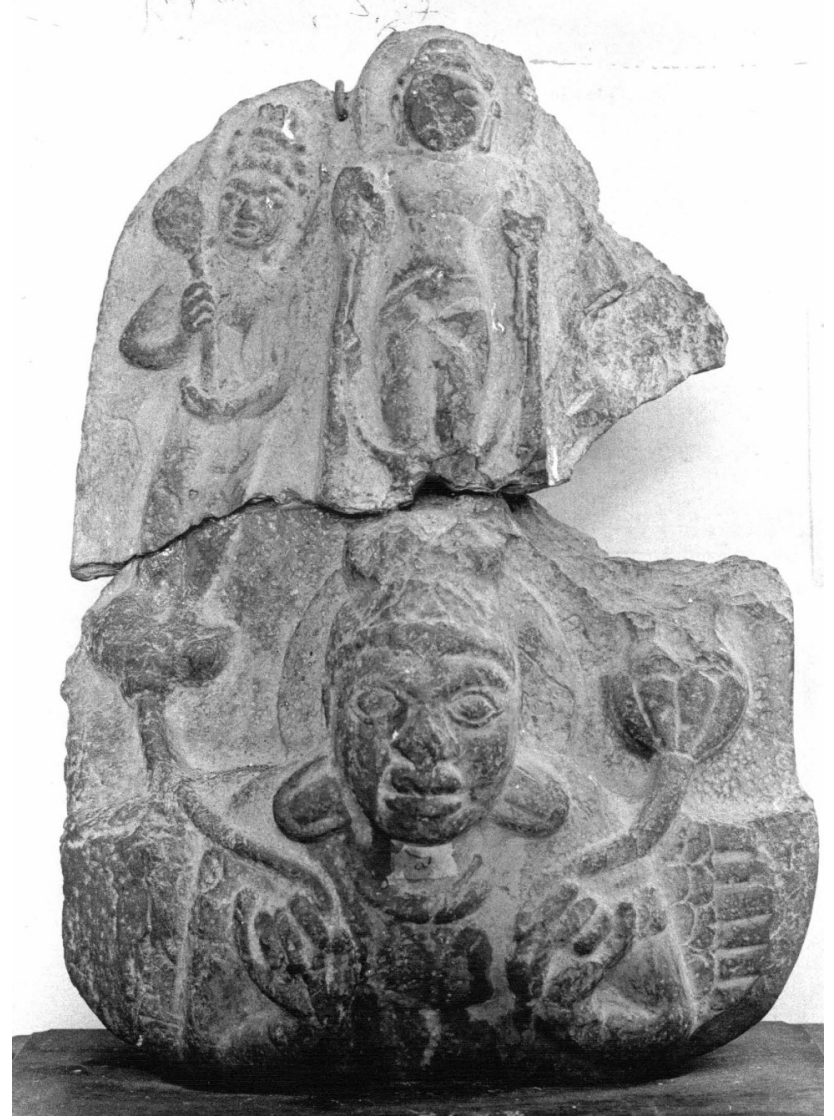

Figure 4. Buddha flanked by figures standing on a mythical creature. From Thailand, 8th to 9th century. Stone, $46 \mathrm{~cm}$ high, National Museum, Ayutthaya.

eyebrows that are turned up at the bridge of the nose, producing a frown. It has small curling horns and pig-like ears. The body is round with two small paw-like feet, each with five clawed toes. The wings fan out to the sides; the two flanking figures stand on these outstretched wings, while the Buddha stands on the animal's head. This apparent composite animal has no textual description or comparative visual depictions. In the context of Indic imagery, only Garuda is suggested, although the texts never point to the Buddha riding on Garuda. ${ }^{4}$ We know of some twenty stone reliefs of the Buddha on the monster ${ }^{5}$, and the comparison of LACMA's example with some of these creates even more ambiguities as there is little iconographic consistency. In some examples the flanking figures appear to be generic figures, more or less identical to one another, and could be attendants or bodhisattvas (Figure 2). There are examples as well of the Buddha alone and without any attendants (Figure 3 ). Likewise, the animal on which the Buddha appears to ride varies tremendously. Some examples appear clearly to be Garuda, and are human in form although they have a bird- 


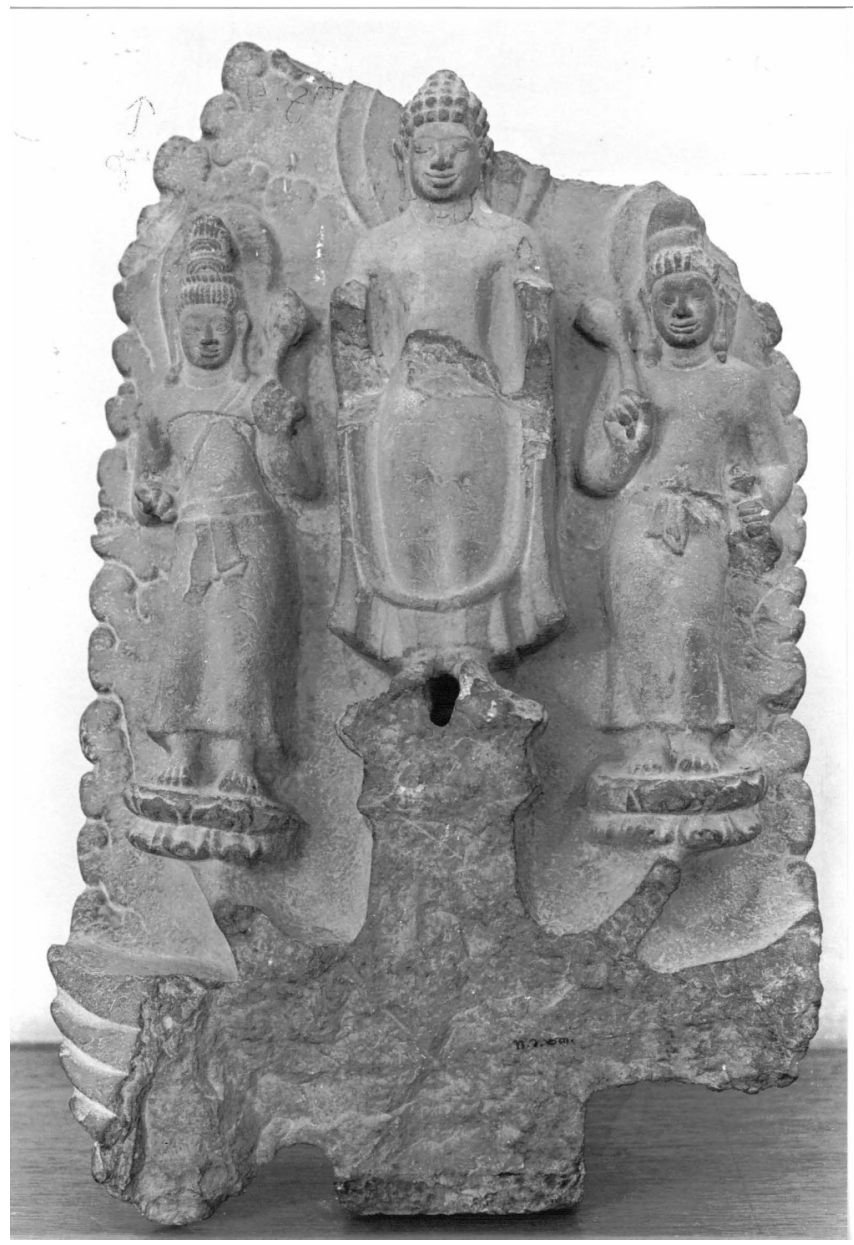

Figure 5. Buddha flanked by figures standing on a mythical creature. From Thailand, 8th to 9th century. Stone, from Khok Samrong District, Lopburi Province, 61cm high, National Museum, Bangkok.

like nose and wings (Figure 4). It is tempting to identify such images as Surya, the sun god. Garuda, the vehicle of Visnu, is often shown holding his hand symmetrically in front of his body while holding two snakes, whereas Surya holds two lotuses in the same way. On the Dvāravatī reliefs, only the two lotuses are held. The upturned lotus blossoms can form the platforms on which the flanking attendant figures stand. But even the human form of a possible Surya has a bird-like nose, suggesting a Garuda/Surya combination. That the triad is intended to be flying is indicated not only by the monster's outstretched wings, but also by examples on which lobed cloud motifs are shown surrounding the figures (Figure 5). Neither the identification of Garuda or of Surya as a vehicle for Buddha and his attendants finds support in Buddhist textual or artistic sources. And neither Garuda or Surya is a possible identification for the examples with the horned

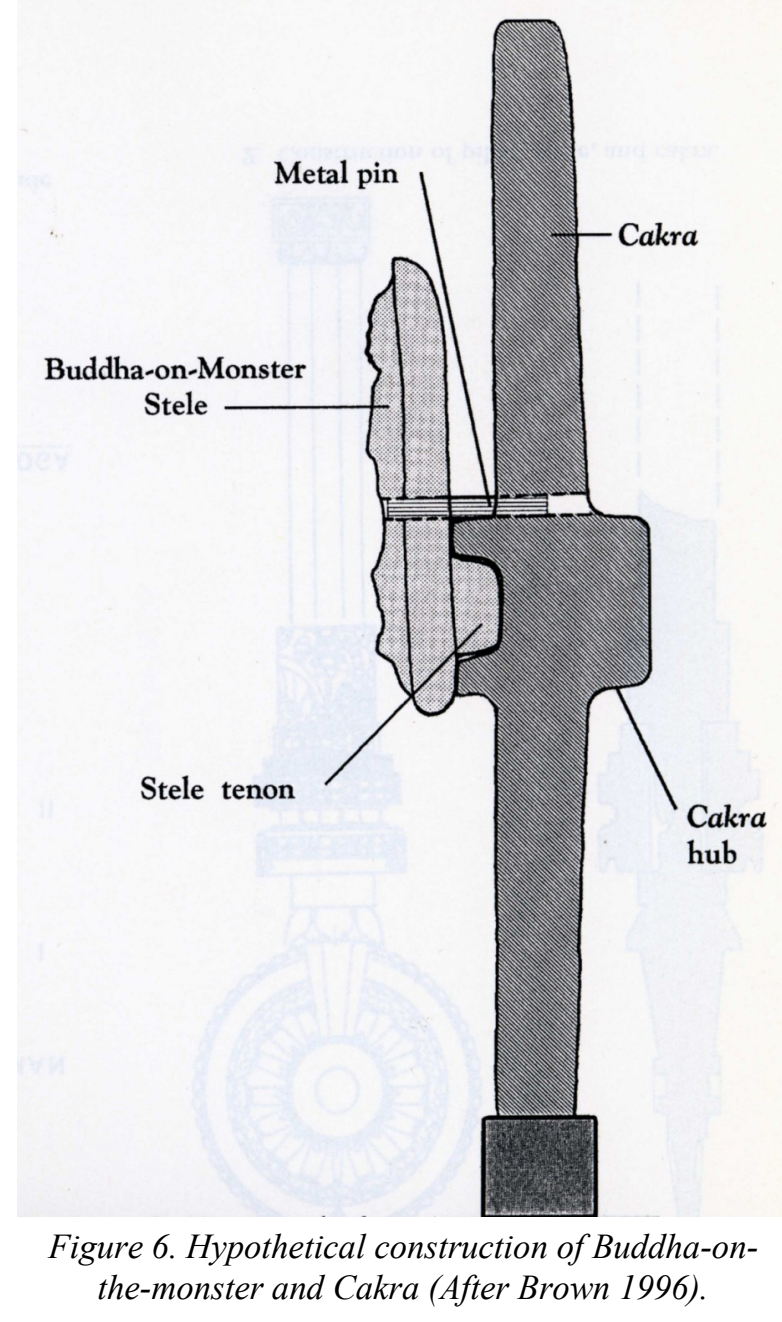

composite animals, such as that on which the LACMA triad rides.

The LACMA relief has a startling detail: a rather crude hole drilled through the center of the stele that goes through the Buddha image. In fact, most of the reliefs have this hole. I have argued that the hole was used to help attach the sculptures to the Wheels of the Law (dharmacakras) that were raised on pillars and held in place by socles, a unique assemblage found only in the art of Dvāravatī (Brown 1996). The original placement of the reliefs must be reconstructed theoretically, as none have been found in an archaeological context. I suggested in 1996 that the Buddha-on-the-monster reliefs were placed at the center of the stone Wheels of the Law, with the drilled hole used for an iron or wood bar that went into a hole in the wheel to help hold the sculptures together (Brown 1996, figs. 2, 3, \& 4). Supporting this hypothesis is a projection of stone on the back of many of the reliefs (including the LACMA relief), and a corresponding depression carved at the center of the wheel hubs, in which 


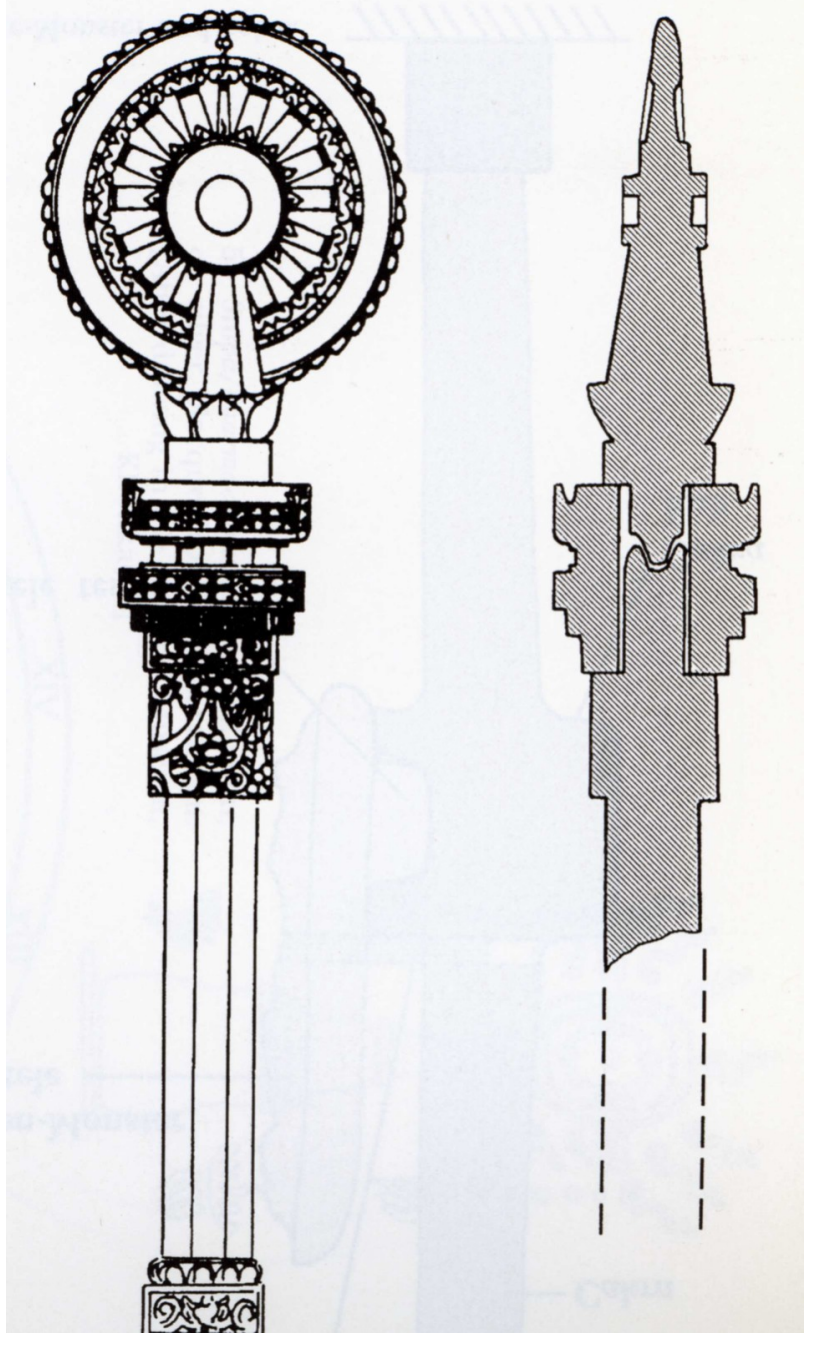

Figure 7. Drawing showing hypothetical construction of Wheels of the Law on stone pillars. (After Brown 1996).

the projections would arguably fit. In addition, there are holes drilled into the wheel hubs that would align with the holes in the reliefs, in order to accommodate a metal or wood bar (Figure 6). This is additional evidence that the two sculpture types were intended to fit together.

The placement and meaning of the triad reliefs has recently been the focus of additional scholarly research. One scholar, Rungrot Thamrungrueang, reviewed the various theories for the placement of the reliefs and concluded that their attachment to the hubs of the Wheels of the Law is the most convincing theory (Thamrungrueang 2006, 2009). We know that the Wheels themselves were sometimes elevated on stone pillars (Figure 7). ${ }^{6}$ The Wheel of the Law elevated on a pillar is among the earliest Buddhist monuments we have, dating to the Mauryan period in India ( $3^{\text {rd }} \mathrm{c}$. BCE), and

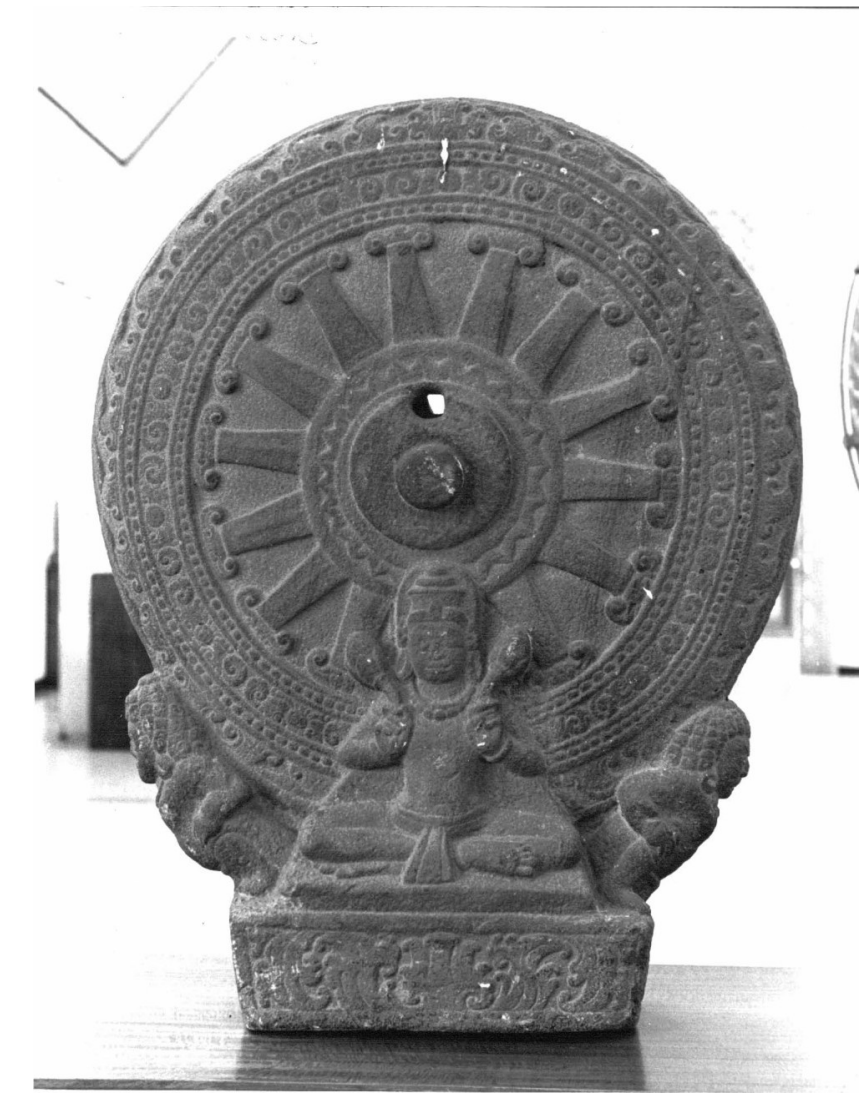

Figure 8. Cakra. From Thailand, 8th to 9th century. Stone, from Nakhon Province, $72 \mathrm{~cm}$ high, National Museum, Bangkok.

is the topic of innumerable stone reliefs on the early Buddhist stupas in India. Yet, as actual freestanding monuments, they exist only in South Asia and Thailand. The triad reliefs associated with the Wheels only exist in Thailand.

Assuming the triads' elevated placement, association with the Wheel, and inherent iconography, what did they mean? We can begin by examining the Wheels of the Law, as they have clear references that we know were part of Dvāravatī Buddhism. The Wheel represents the Buddha's teachings or Law (Skt. dharma, Pali dhamma) with the imagery of his turning the Wheel of Law in his First Sermon, an action that sets the Wheel rolling across the landscape and spreading his teachings. This is the basic meaning of the Wheel in the thousands of depictions of it throughout the Buddhist world. However, it is stated clearly in the examples of the Dvāravatī Wheels, where the famous contraction of the First Sermon, the Four Noble Truths, is directly inscribed:

The knowledge of the truth,

The knowledge of what should be done,

The knowledge of what has been done. ${ }^{7}$ 


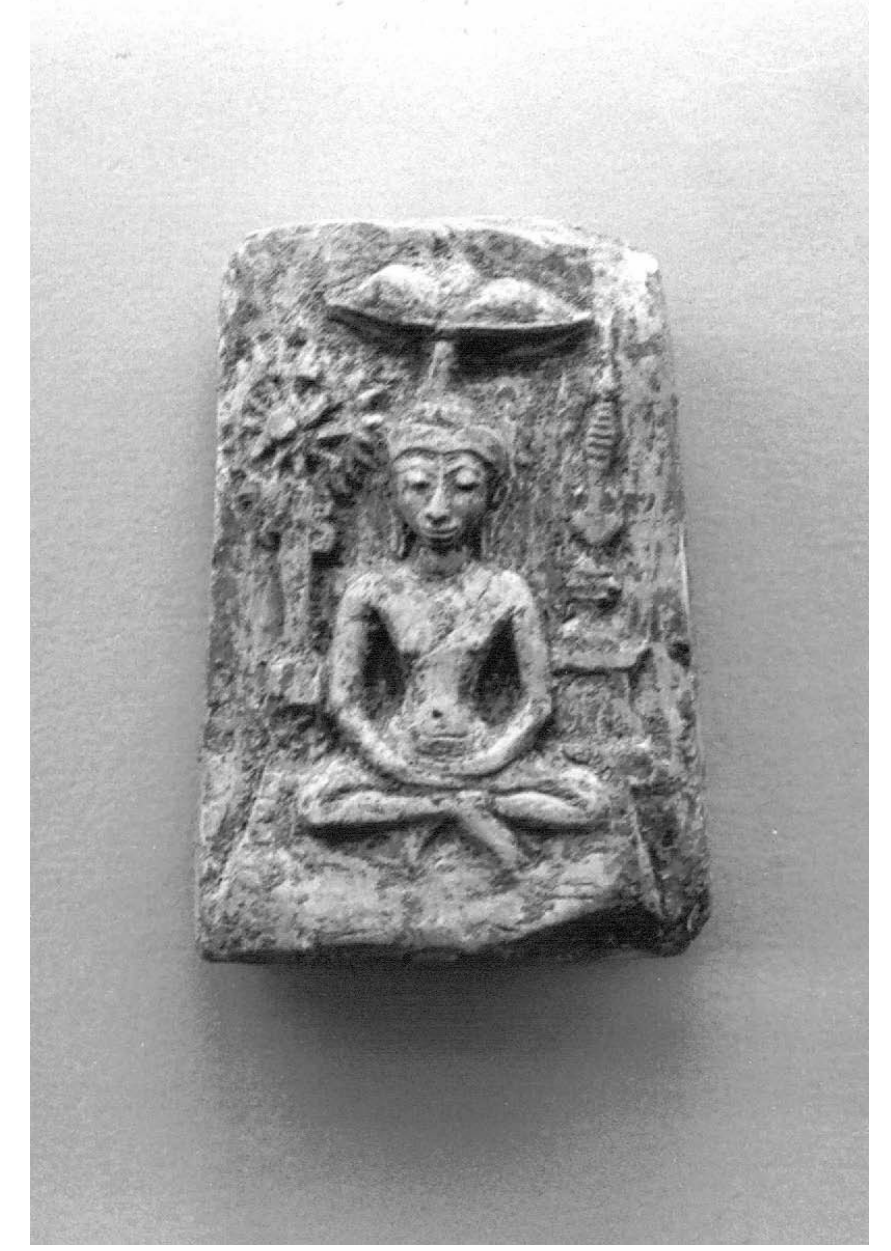

Figure 9. Buddha between Cakra and Stupa. From Thailand, 8th to 9th century. Terra cotta, National Museum, Bangkok.

The First Sermon reference is expanded in other Wheel inscriptions, in which the "truth" of the formula given above, the Four Noble Truths, is expanded by a $3 \times 4$ pattern into twelve statements. ${ }^{8}$ These various inscriptions relating to the Buddha's First Sermon are arranged on the Wheels around the hub, the felly, and on the spokes, the idea being that they should be read as the wheel turns.

A second Buddhist reference to the Wheel refers to it as the bhavacakka (Skt. bhavacakra) or the Wheel of Becoming. Based on inscriptions on some of the Dvāravatī Wheels, they are likely to be bhavacakka. On several Wheels the twelve links of the Chain of Causation (paticcasamuppada) are inscribed. These are a series of twelve cause and effects that keep a person in the world in serial rebirths that identify the Wheels of Becoming. The Chain of Causation was first realized by the Buddha when he reached Enlightenment at Bodhgaya, and is another elaboration of the Four Noble
Truths, and thus a clear link to the First Sermon imagery of the Dvāravatī Wheels. ${ }^{9}$

A final Buddhist reference for the Dvāravatī Wheels is more difficult to prove: the Wheel attribute of the Universal Buddhist King or cakravartin, who is another wheel turner like the Buddha but in the secular realm of kingship and political power. Here the wheel is seen as a weapon or as a represention of the wheels of a war chariot. In Indian art the cakravartin's wheel is shown in relief sculpture raised on a pillar (Ramachandra Rao 1984, Figure 158). It may have had that significance in Dvāravatī art as well, and two scholars argue that the Buddha on the monster iconography has a specific political intention (see below). We can verify that the term cakravartin was known in an area of Thailand related to Dvāravatī, as it is inscribed (spelled "cakravarti") on a votive tablet from Amphoe Nadun, Mahasarakham Province (see Skilling 2008, p. 251).

The wheel had other meanings in South and Southeast Asian religious and mythic symbolism. The most important meaning for us as a symbol of the sun. The wheel's solar imagery is seen repeatedly in South Asian texts, both Hindu and Buddhist, and in art, from the wheel held by the Hindu god Visnu to the wheels of the chariot in which the sun god Surya rides across the sky each day. The solar imagery of the Dvāravatī wheels is clearly indicated by the examples in which Surya is depicted on some of the wheels (Figure 8; see Brown 1996, Figures 22a,b, 24a,b, \& 26a).

In summary, the Dvāravatī Wheels represent the Buddha's First Sermon, or more generally his teachings or dhamma, and also have a solar reference. How, then, might the monster triads have related if they were placed on the hubs of the Dhamma Wheels? The most obvious connection would be that the Buddha images were intended to be teaching the dhamma and preaching the Law from the sky. This is based on their raised position on the pillars, as well as the indications of flying, cloud motifs on some reliefs, and references to the sun. This rather obvious suggestion has never been proposed, possibly due to the hand gestures of the Buddhas, which show a variety of combinations that include vitarka, abhaya, and kantaka mudras. They do not exclusively perform the gesture that one assumes would indicate the act of teaching, at least in First Sermon scenes, which for Dvāravatī Buddha images is vitarka mudra (the hand open with the thumb and index finger touching, see Brown 1996, Figure 68). The gesture that one might expect for teaching, and is seen on images throughout most of the Buddhist world, is the dharmacakra mudra, that in which the hands are held together in front of the body. The dharmacakra mudra is not, however, used in Dvāravatî art.

The Dvāravatī examples we have that clearly depict the First Sermon being taught show the Buddha seated with his legs pendant (pralambapada asana), his right hand raised in vitarka mudra, and his left hand open in his lap (Brown 
1996, Figure 68). But this iconography is not restricted to teaching in Dvāravatī art. ${ }^{10}$ Standing figures of the Buddha in Dvāravatī art often also have the vitarka mudra, but it is usually being performed with both hands raised symmetrically. We do not know what this dual gesture means (see Tingsanchali 2009, pp. 225-227). In short, we do not know what hand gestures the Dvāravatī artist might choose to represent a preaching Buddha shown standing; but there is no reason that the three hand positions used for the Buddhas on the monster could not be used.

The Buddha teaching the Law while in the sky is widely found in Buddhist texts. The Buddha performs, at a variety of times and places, the miracle of walking or standing in the sky in order to preach the dhamma. For example, among the miracles he performed at Sravasti was to rise into the sky, create doubles of himself in various postures, and propose and answer questions regarding the dhamma. The Sravasti miracles are a popular theme for Dvāravatī relief depictions (Brown 1984b). When performing this miracle of doubling himself, the Buddha is flanked by Indra and Brahma. This is described in the Divyavadana, which accords with examples such as that of LACMA (Chirapravati 1997, p. 21). The point of the sky lectures is conversion, as it is one way in which the Buddha awes his audience on the ground and convinces them of the authority of the Law. Thus, the Dvāravatī Buddhas on Monsters might represent sky teaching with the Wheels of the Law indicating the dhamma itself. Rather than a search (which has thus far been unsuccessful) for a narrative in which to embed the flying Buddha, we might think of the imagery used to indicate a place-the sky-where the Buddha is performing a sky-lecture. This sky imagery fits as well with the examples of the Buddha in association with clear images of Surya. It also accords nicely with my arguments regarding the aerial palace that was used as a socle on one of the wheel pillars (Brown 1984). The placement of the Buddha in the sky is common among this imagery. The purpose is not to tell a story, but to enable the Buddha to preach the Law to those on Earth, and more literally to those who stand on the ground below the Dvāravatī pillars.

Sara Tiffen and Martin Stuart Fox (2002) recently made an attempt to link the Buddhas on monsters iconography to political goals. They have argued that the Buddha on the monster steles are connected to the Dvāravatī kings' need to legitimize their rule. Tiffin and Stuart-Fox connect the steles to the ritual of anointing the king through water lustrations (abhisheka). Without any Dvāravatī historical sources, they rely on a comparative methodology with royal practices in India and Burma, and suggest the Buddha on the monster iconography indicates the use of Hindu, Buddhist, and solar symbolism to show royal legitimation. The article, while tentative, is a welcome attempt to move Dvāravatī art away from a strictly religious orientation.
Finally, how might the LACMA triad have been placed, assuming it was once on the hub of a Wheel of the Law and raised on a pillar? With the lack of standing pillars and archaeological evidence, it is difficult to know where the cakras-and thus the triads - would have been placed during the Dvāravatī period. ${ }^{11}$ However, we do have a series of small votive tablets that depict the Wheel pillars in conjunction with a Buddha figure and a stupa (Figure 9) (see Brown 1996, Figures 80, 81, 82, 85, 86, 87). The Buddha is at the center flanked by a stupa and a Wheel pillar. Therefore, it seems likely that this arrangement reflects, in a broad outline, the three major Buddhist monument types of the period. This suggests that the Wheel pillars with the Buddhas on the Monster would have been erected in conjunction with Buddha images (probably in an image house) and a stupa.

\section{NOTES}

1. At times, the verbal description of how the Buddha's robe can be worn can be difficult to follow. For a discussion of how the robe was worn, with illustrations and drawings, see Griswold 1963.

2. See, for example, the description in Burlingame 1979, pp. 47-56 (this is the commentary of the Pali Dhammapada - the Dhammapadatthakatha).

3. The importance of the subordination of Indra and Brahma to the Buddha has been stressed and discussed by John Huntington (Huntington 1986, pp. 42-43). He writes that it is "the single most important statement of the entire set of the Astamahapratiharya [the eight events of the Buddha's life with their specific geographical locations that became standard depictions in the art of India from the $8^{\text {th }}$ century on]" (p. 43).

4. Thai scholarly sources often name the animal Banaspati or Phanasbodi, or Lord of the Forest, although this is a modern designation (see Woodward 2003, p. 61).

5 . There is no source for the total number of such images. Complicating this, that there are forgeries, which would have to be studied and removed from the count. There are also examples in collections that are not published. Thus, the figure of some twenty is simply a guess (probably an underestimate)

6. None of the Wheel and pillar assemblages is extant today, although one set of pillar, socle, and Wheel were found together in an excavation at $U$ Thong. However, no triad relief was found with them. We do not know if the Wheels were set up on the ground-something certainly possibile, judging from small votive tablets that appear to show this arrangement - or if wood was used at times for the pillars. See Brown 1996, 1984. 
7. This is the translation of the example on Cakra \#5 in Brown 1996, p.99.

8. The Four Noble Truths are: suffering, its origins, its stopping, and the method of stopping. Each of the four Noble Truths is stated in terms of the knowledge of the truth, the knowledge of what should be done, and the knowledge of what has been done.

9. See Brown 1996, pp. 115-120, for a discussion of the bhavacakra and the twelve links of causation.

10. It is used when he performs the Sravasti miracles of producing the mango tree from a seed and twinning himself, for example, in a magical display, and thus is not an instance of teaching the Law (see Bowie 1960, fig. 17).

11. The Dvāravatī-period sculpture was moved over time, even during the modern period, in conjunction with Buddhist monuments or at Buddhist monasteries. The original provenance of almost all of the sculpture remains unknown today.

\section{REFERENCES}

Baptiste, Pierre, and Thierry Zephir. 2009. Dvāravatī: aux sources $d u$ bouddhisme en Thailande. Paris: Musee Guimet.

Beal, Samuel . 1884. Si-Yu-Ki. Buddhist Records of the Western World. Translated from the Chinese of Hiuen Tsiang (A.D. 629). Translated. London: Kegan Paul, Trench, Trubner \& Co.

Bowie, Theodore. 1960. The Arts of Thailand. Bloomington: Indiana University.

Brown, Robert L. 1990. God on Earth: The Walking Buddha in the Art of South and Southeast Asia. Artibus Asiae 50 (1/2): 73-107.

Brown, Robert L. 1984a. Indra's Heaven: A Dharmacakrastambha in the Bangkok National Museum. Ars Orientalis XIV: 115-130.

1984b. The Sravasti Miracles in the Art of India and Dvāravatī. Archives of Asian Art 37: 79-95.

Burlingame, Eugene Watson. 1979. Buddhist Legends: Translated from the original Pali text of the Dhammapada Commentary. London: The Pali Text Society.

Chirapravati, ML Pattaratorn. 1997. Votive Tablets in Thailand: Origin, Styles, and Uses. Kuala Lumpur: Oxford University Press.
Dalsheimer, Nadine. 2001. Les collections du musee national de Phnom Penh: L'art du Cambodge ancien. Paris: Ecole francaise d'Extreme-Orient.

Dupont, Pierre. 1955. La statuaire preankorienne. Ascona: Artibus Asiae.

Griswold, A. B. 1963. Prolegomena to the Study of Buddha's Dress in Chinese Sculpture, Part I. Artibus Asiae 26: 85131.

Huntington, John. 1986. Sowing the Seeds of the Lotus: A Journey to the Great Pilgrimage Sites of Buddhism, Part III. Orientations 17(3): 32-46.

Ramachandra Rao, P.R. 1984. Andhra Sculpture. Hyderabad: Akshara.

Skilling, Peter. 2008. Buddhist Sealings in Thailand and Southeast Asia: Iconography, Function, and Ritual Context. In E.A. Bacus, I.C. Glover, and P.D. Sharrock (eds), Interpreting Southeast Asia's Past: Monument, Image and Text. Selected Papers from the $10^{\text {th }}$ International Conference of the European Association of Southeast Asian Archaeologists, Vol. 2, pp. 248-262. Singapore: NUS Press.

Thamrungrueng, Rungrot. 2006. The Dharmacakra from Northeastern Thailand. Muang Boran, 32(1): 72-85. (in Thai).

Thamrungrueang, Rungrot. 2009. L'image du Buddha sur Phanasbodi. In Pierre Baptiste and Thierry Zephir (eds), Dvāravatī: aux sources du bouddhisme en Thailande. Paris: Musee Guimet.

Tiffin, Sarah, and Martin Stuart-Fox. 2002. Dvāravatī 'Buddha on a Monster' Stelae: A Possible Interpretation. Journal of the Royal Asiatic Society 12 (1): 47-65.

Tingsanchali, Chedha. 2009. Les representations du Buddha en double vitarka mudra. In Pierre Baptiste and Thierry Zephir, Dvāravatī: aux sources du bouddhisme en Thailande. Paris: Musee Guimet.

Woodward, Hiram. 2003. The Art and Architecture of Thailand: From Prehistoric Times through the Thirteenth Century. Leiden: Brill. 